\title{
GEOMETRY GEOMETRIE
}

\begin{abstract}
ED NATURE
Amongst the specific properties of wood as a construction material, the moments of bifurcation are one of the most particular characteristics that constitute its irregular nature. When considered as standard building material, these singularities represent disruptions to an otherwise homogenous performance. However, looking at wood in its original form, as a less abstracted entity, bifurcating branches appear as integral elements in the structural system of a tree. From this perspective, the alleged 'disturbances' appear as optimized nodes, allowing for a continuous flow of forces. $\nearrow^{23}$
\end{abstract}

Can we make use of this intelligence in construction? What if wood were used as a form, rather than as an abstracted material?

In pre-industrial times, specific grown forms of trees were used as hand tools, ${ }^{1}$ selected as high-performance components for shipbuilding (Fig. 1) and in traditional vernacular architecture in Japan. $\nearrow^{24}$

In contemporary architectural research, examples of an approach to utilizing such forms are starting to appear, e.g., the Wood Chip Barn project, ${ }^{2}$ in which Y-shaped tree forks were used to approximate a truss. Building on such precedents, Branch Formations on the other hand aims at deriving possible spacedefining and structural schemes from the inherent characteristics of wood, deliberately waiving a predefined application. To develop a bottom-up, material-based methodology, both branch-part characteristics and their relationship to one another are the two main criteria to be investigated.

The most challenging aspect is the irregular geometry of branch parts. Such non-standard elements can hardly be processed within a standard industrial production chain and the uniqueness of each part introduces the challenge of organizing complex data sets. $\nearrow^{25}$

\section{ABSTRAHIERTE NATUR}

Betrachtet man Holz als Baumaterial, zählen die Gabelungen zu den vielen spezifischen Eigenschaften und sind ein besonderes Merkmal, das seine unregelmäßige Natur ausmacht. Wird Holz als Standard-Baumaterial eingesetzt, stellen diese Singularitäten Unterbrechungen einer homogenen Leistungsfähigkeit dar. Betrachtet man Holz jedoch in seiner ursprünglichen Form, als ein weniger abstrahiertes Gebilde, stellen Astverzweigungen integrale Elemente im strukturellen System eines Baumes dar. Aus dieser Perspektive erscheinen die vermeintlichen Störungen als optimierte Knotenpunkte, die einen kontinuierlichen Kraftfluss ermöglichen. $\nearrow^{23}$

Können wir diese Intelligenz für Konstruktionen nutzen? Was wäre, wenn Holz als Form und nicht als abstraktes Material verwendet würde?

In vorindustrieller Zeit wurden spezifische Wuchsformen von Bäumen als Handwerkszeug verwendet, ${ }^{1}$ als Hochleistungsbauteile für den Schiffsbau ausgewählt (Abb. 1) und teilweise auch in der traditionellen Architektur in Japan eingesetzt. $\nearrow^{24}$

In der zeitgenössischen Architekturforschung tauchen bereits erste Beispiele für einen Ansatz zur Nutzung solcher Formen auf, zum Beispiel im Projekt Wood Chip Barn, ${ }^{2}$ bei dem y-förmige Baumgabeln zusammengefügt wurden, um in Annäherung einen Fachwerkträger zu bilden.

Aufbauend auf solchen Beispielen zielte Branch Formations darauf ab, mögliche raumdefinierende und strukturelle Schemata aus den inhärenten Eigenschaften von Holz abzuleiten, wobei bewusst auf eine vordefinierte Nutzungsmöglichkeit verzichtet wurde. Um eine materialbasierte Bottom-up-Methodik zu entwickeln, waren sowohl die Eigenschaften der Teile als auch ihre Beziehung zueinander die beiden Hauptkriterien, die es zu untersuchen galt.

Der herausforderndste Aspekt war die unregelmäßige Geometrie von Astgabeln. Solche nicht standardisierten Elemente können kaum innerhalb einer industriellen Standard-Produktionskette verarbeitet werden, und die Einzigartigkeit jedes Teils bringt die Herausforderung mit sich, komplexe Datensätze organisieren zu müssen. $\nearrow^{25}$

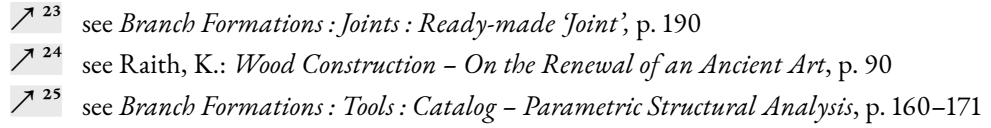


Unten

Auswahl des Schiffbauholzes. Stich. - Aus: Encyclopédie Methodique, 1787, Tafel 100

Links

Aus einer Astgabel (oben) wird mit dem Beil ein Kniestück (unten) herausgearbeitet. Stich. - Aus: Instruction, 1804 Tafel 27
Gelenkketten (Ledemall) zum Übertragen von Kurven. Dieses Werkzeug war Eigentum jedes Zimmermanns, das er in einer Kiste ebenso aufbewahrte wie auch das Kalfatwerkzeug zum Dichten der Plankennähte mit Werg und Pech. Mit dieser, meist von ihm ausgeschmückten Kiste war er relativ beweglich und konnte in Zeiten mangelnder Arbeit als Schiffszimmermann auf Segelschiffen anheuern.

Die Werft stellte die Hebezeuge wie Hubschrauben, Winden oder Taljen, die an provisorisch aufgestellten Böcken angebracht wurden. Vereinzelt waren auch große, feste Kräne für das Einsetzen der Masten im Gebrauch wie das Danziger Krantor, das 1444 vollendet wurde. Mechanische Werkzeuge kamen erst später auf. Beim Bau der größten Holzklipper setzte der Amerikaner Donald MacKay um 1850 bereits dampfbetriebene schwenkbare Bandsägen ein, um Spanten mit schrägen Außenseiten - mit Schmiege - aussägen zu können.

Der Aufwand eines Schiffbaus führte früher als bei anderen Handwerkszweigen zur Arbeitsteilung. Bereits bei de

den

(stafn

jeder

Plank

ster,

Helfe

baus

Helfe

Schrr

macr

Die

Küns

gefar

auch

außeI

Die

Haus

öfters

lige $F$

Ports

3 Fuf

Einflı

ser $\mathrm{g}$

Inc

der

frems

oder

den 1

das $t$

eine

Lehrt

Aufn:

Im

Anza

zeit 1

eines

Hiere

Sie 1

aber

Der

Die E

fahre

es ur

ausrı

A Fig. 1 | Abb. 1:

Selection of wood for shipbuilding, from: Encyclopédie méthodique, Paris 1787 (scanned page from: Broelmann, J.: Schiffbau - Handwerk, Baukunst, Wissenschaft, Technik).

Source: 'Deutsches Museum, München, Bibliothek, 2000/Gesch. 650.109'. 
A comparison of tree species shows that deciduous trees form crowns and branches with larger diameters, suggesting that hardwood branches are more suitable as ready-made components than those of coniferous trees. Crowns account for a significant portion of a tree and are typically disregarded for construction, leaving a lot of its potential unused. This becomes especially problematic when considering climate change. Projections in forestry research ${ }^{3}$ for Central Europe show that the stocks of the most commonly used conifer species like spruce will decrease because deciduous trees seem to be more robust in warmer and drier climates. ${ }^{4}$ This underscores the relevance of a technique that makes use of neglected yet valuable resources. $\nearrow^{26}$

Simplifying branches as abstracted digital models is the base condition for a systematic working method. 3D-scanned elements can be translated into axis models, allowing for studies and simulations with large sets of digital parts. $\nearrow^{27}$

\section{JOINING PRINCIPLES}

The growth pattern of trees forms strands of fibers, which constitute the distinctly heterogeneous characteristic of wood.

To activate the structural potential of this property, branch parts are joined along their grain orientation, thus following the principle of the natural system. $\nearrow^{28}$

However, as an artificial entity, a reconfiguration of the natural elements allows for a modification of the original that embeds new functionalities. The naturally cantilevering branches can be rearranged into closed loops, forming structural cells and providing a greater versatility as components for architectural purposes (Fig. 2). To compensate for the large variety of forms and different branch lengths within a flexible design system, aggregates can be joined using linear bridging elements (Fig. 3). Joining parts directly requires a lesser amount of joints, but also requires a more precise selection mechanism in order to match the available specimens (Fig. 4). The limitation of this geometric flexibility has the advantage of creating frameworks with increased stability, therefore the latter approach was pursued in this project.
Ein Vergleich von Baumarten zeigt, dass Laubbäume Kronen und Äste mit größeren Durchmessern bilden, was darauf hindeutet, dass sich Äste aus Hartholz (von Laubbäumen) besser als Fertigteile eignen als die von Nadelbäumen. Die Krone stellt einen beträchtlichen Teil eines Baumes dar, der typischerweise für Konstruktionen nicht beachtet wird, wodurch viel Potenzial ungenutzt bleibt. Dies wird besonders problematisch, wenn man den Klimawandel mit einbezieht. Prognosen der Wald-Forschung ${ }^{3}$ für Mitteleuropa zeigen, dass die Bestände der am häufigsten verwendeten Nadelbaumarten wie der Fichte abnehmen werden, da Laubbäume robuster gegenüber wärmerem und trockenerem Klima zu sein scheinen. ${ }^{4}$ Dies unterstreicht die Relevanz einer Vorgehensweise, die auf vernachlässigte, aber wertvolle Ressourcen zurückgreift. $\nearrow^{26}$

Die Vereinfachung von Ästen zu abstrahierten digitalen Modellen ist die Grundvoraussetzung für eine systematische Arbeitsweise. 3D-gescannte Elemente wurden zunächst in Achsmodelle übersetzt, was Studien und Simulationen mit großen Mengen digitaler Daten und präzise Berechnungen ermöglichte. $\nearrow^{27}$

\section{FÜGEPRINZIPIEN}

Das Wachstumsschema von Bäumen bildet Faserstränge aus, die die ausgeprägte heterogene Eigenschaft von Holz ausmachen.

Um das strukturelle Potenzial dieser Eigenschaft zu aktivieren, wurden die Äste entlang ihrer Faserorientierung und damit entsprechend dem Prinzip des natürlichen Systems verbunden. $\nearrow^{28}$

Als künstliches Gebilde erlaubt eine Re-Konfiguration der natürlichen Elemente jedoch eine Modifikation des Originals, um neue Funktionsweisen mit einzubeziehen. Die von Natur aus auskragenden Äste lassen sich zu geschlossenen Gebilden zusammensetzen, sodass sie strukturelle Zellen bilden und als Bauteile für architektonische Zwecke vielseitiger einsetzbar sind (Abb. 2). Um die große Formenvielfalt und die unterschiedlichen Astlängen innerhalb eines flexiblen Konstruktionssystems zu kompensieren, können Aggregate mit linearen Überbrückungselementen verbunden werden (Abb. 3). Das direkte Verbinden von Teilen erfordert eine geringere Anzahl von Verbindungsstellen, macht aber einen präziseren Auswahlmechanismus notwendig, um die verfügbaren Exemplare zuzuordnen (Abb. 4). Die Einschränkung dieser geometrischen Flexibilität hat allerdings den Vorteil, dass Fachwerke mit erhöhter Stabilität entstehen, daher wurde dieser Ansatz in diesem Projekt weiter verfolgt. 



\section{CELLULAR STRUCTURES}

In the context of a concept of spatial frameworks as closed cells (Fig. 5a), these modules can be organized in larger aggregations with a simple repetitive topology (Figs. $5 \mathrm{~b}+\mathrm{c})$. The most compact and stable form is a tetrahedral module (Figs. 6a-c). The predictability of this concept enables a robust setup for a flexible workflow that integrates an inventory of diverse parts. The design process starts with a regular framework of identical placeholder elements or 'proto-parts', defining an overall layout in a digital model (Fig. 7 top). $\nearrow^{29}$

These substitute items are replaced by irregular elements from the digitized set, and the discrepancies from the regular form result in a discontinuous model (Fig. 7 middle). In a physics simulation in a digital model, gaps between elements are closed, reestablishing the initial topology as a globally deformed model consisting of aligned and overlapping branch elements (Fig. 7 bottom). $\nearrow^{30}$

Sets with varying ranges of angles, representing branches from different tree species, would result in very different formations (Figs. 8a-c).

Furthermore, it was observed that the drying process affected a deformation in the branch forks, which was difficult to predict. The 3D scanning method, which involves a prior marking of elements $\nearrow^{31}$, would allow for precise monitoring of that process as a basis for further research.

The close relationship between material and form in this context indicates a potential for further investigations into material-specific spatial organization and structural models.

\section{ZELLARTIGE STRUKTUREN}

Im Hinblick auf konzeptionelle Raumgerüste aus geschlossenen Zellen (Abb. 5a) ist die kompakteste und stabilste Form ein tetraeder-förmiges Modell (Abb. 6a-c). Diese Module können in größeren Aggregationen mit einer einfachen, sich wiederholenden Topologie organisiert werden $(\mathrm{Abb} .5 \mathrm{~b}+\mathrm{c})$. Die Vorhersagbarkeit dieses Prinzips eröffnet einen soliden Ansatz für einen flexiblen Arbeitsprozess, der auf einem Inventar von diversen (Bau-)Teilen aufbaut. Der Designprozess begann mit einem regulären Raumgerüst aus identischen Platzhalterelementen oder, Proto-Teilen', die in einem digitalen Modell das Gesamtlayout definierten (Abb. 7 oben). $\nearrow^{29}$ Diese Platzhalterelemente wurden durch die unregelmäßigen Elemente aus dem digitalisierten Satz ersetzt, wodurch es zu Abweichungen von der regelmäßigen Form kam und ein diskontinuierliches Gefüge entstand (Abb. 7 Mitte). In einer physischen Simulation im digitalen Modell wurden diese entstandenen Lücken zwischen den Elementen wieder geschlossen. Dadurch wurde die ursprüngliche Topologie in Form eines global deformierten Modells aus zueinander ausgerichteten und ineinander greifenden Astgabeln wiederhergestellt (Abb. 7 unten). $\nearrow^{\mathbf{3 0}}$

Die Verwendung von Datensätzen aus Elementen mit unterschiedlichen Winkeln, die Ästen von verschiedenen Baumarten entsprechen, würde zu sehr unterschiedlichen Formationen führen (Abb. 8a-c).

Zudem wurde beobachtet, dass der Trocknungsprozess eine schwer vorhersehbare Verformung in den Astgabeln bewirkt. Eine 3D-Scan-Methode, die eine Markierung der Elemente vorab voraussetzt, $\nearrow^{31}$ würde eine genaue Erfassung dieses Prozesses als Grundlage für weitere Untersuchungen ermöglichen.

Diese Aspekte verdeutlichen den direkten Zusammenhang von spezifischer, auf eine Baumart bezogener Materialgestalt und der daraus resultierenden Raumstruktur und bieten Raum für weitere Forschungen zu materialspezifischen Raumentwürfen und Strukturmodellen. 


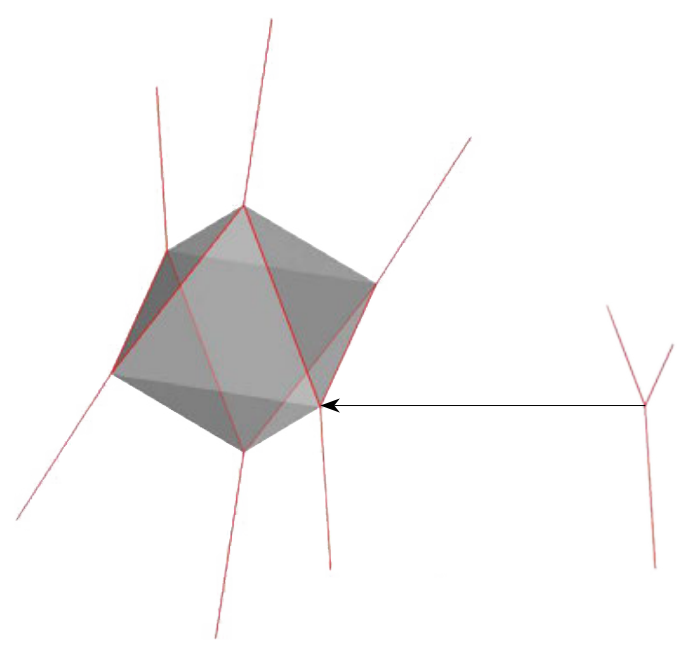

- Fig. 5a|Abb. 5a:

Cellular octahedral module consisting of six Y-shaped branch forks.

V Fig. 5b | Abb. 5b:

Aggregation logic for multiple modules (axis model), each of a regular octahedral grid from identical elements.
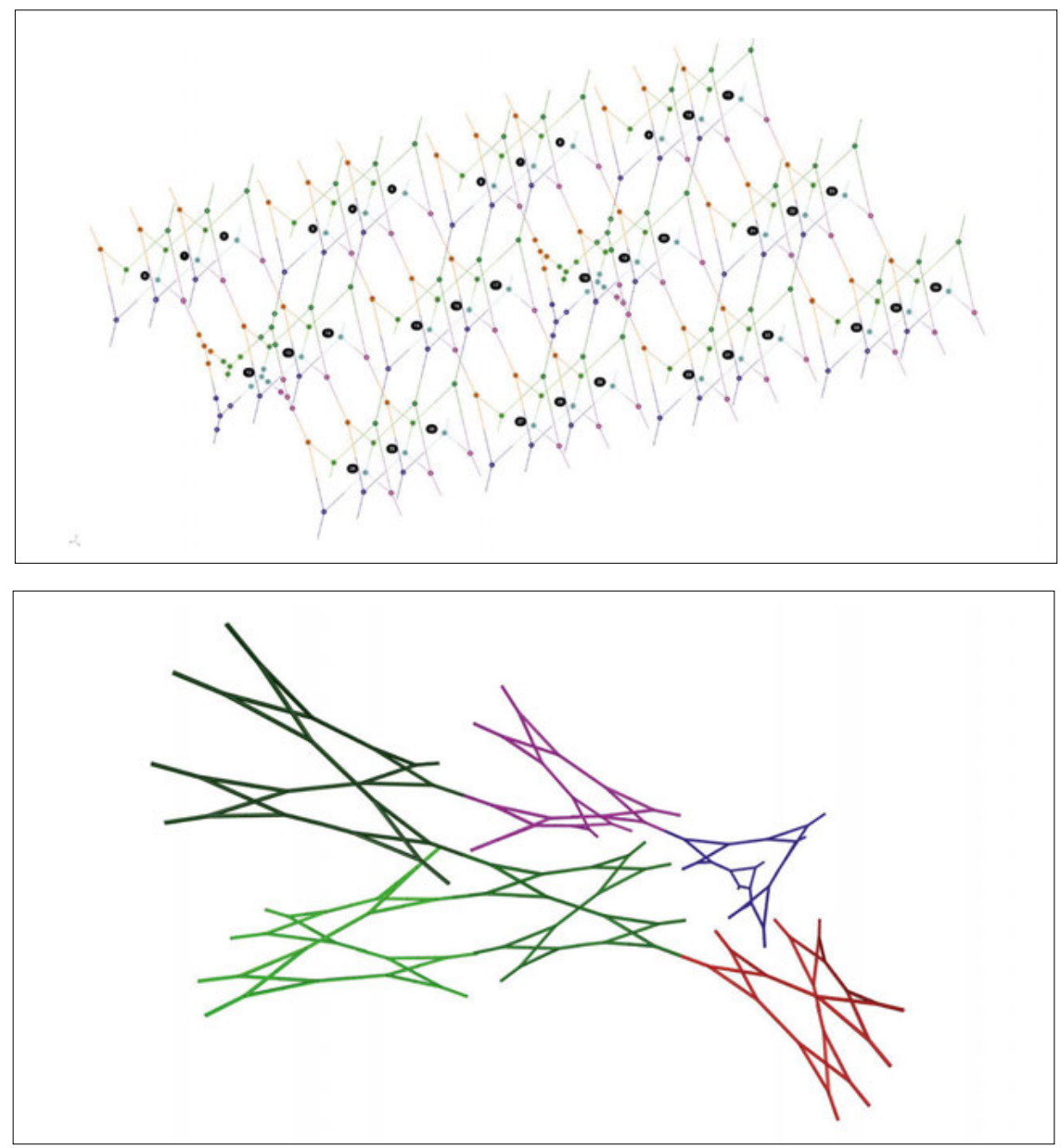

$\Delta$ Fig. 5c| Abb. 5c:

Irregular formation from regular tetrahedral modules (hereby four modules form a larger component, highlighted by colors). 
- Fig. 6a|Abb. 6a:

Diagram of a tetrahedral cell from four Y-shaped branch forks.

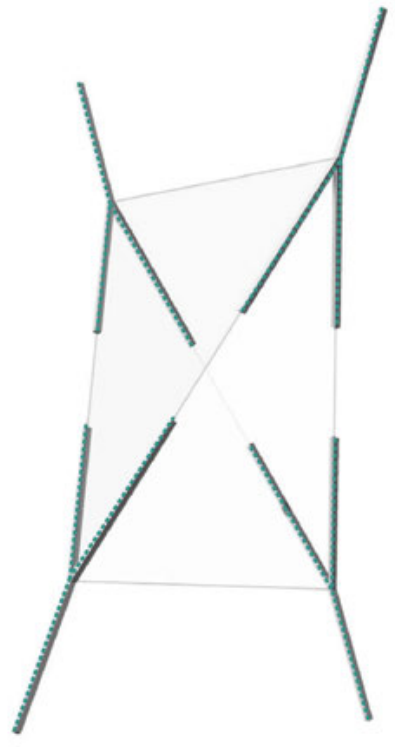

$\{003\}$

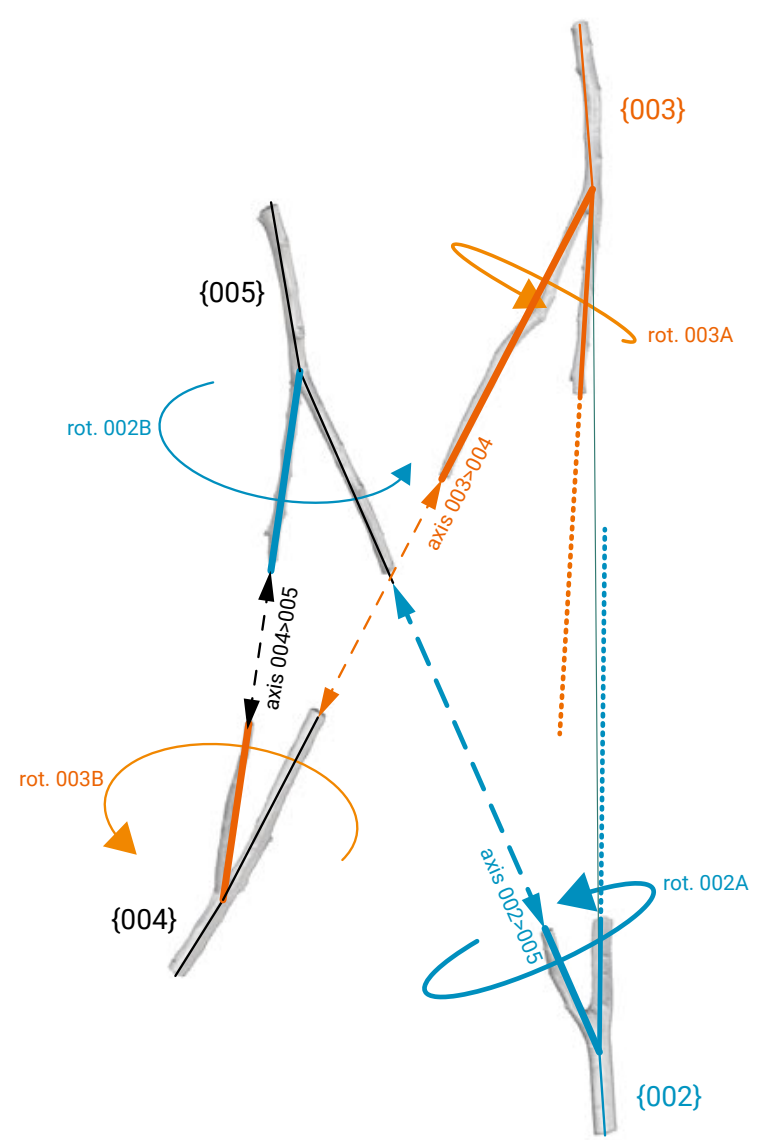

$\Delta$ Fig. 6b | Abb. 6b:

Diagram of the geometric degrees of freedom to form a tetrahedral cell configuration (similar to the kinematic system of a robotic arm).

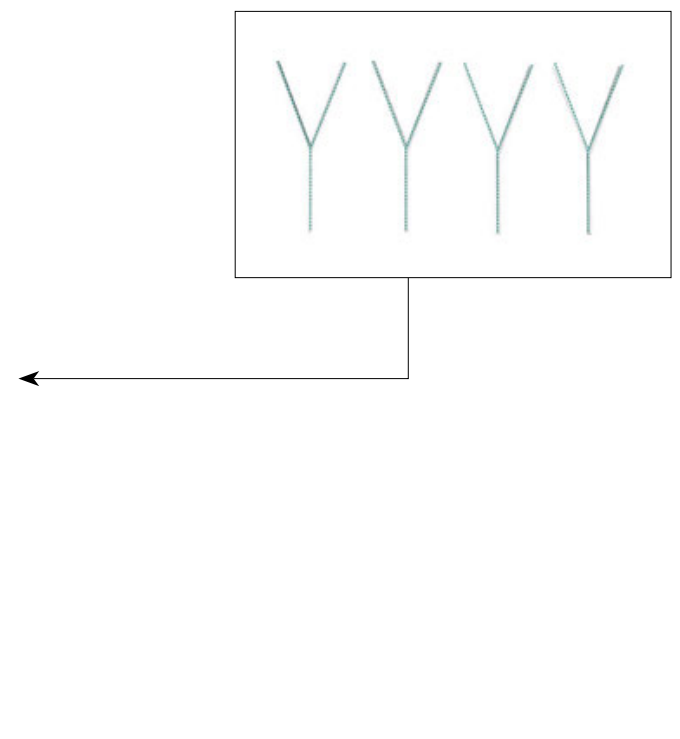

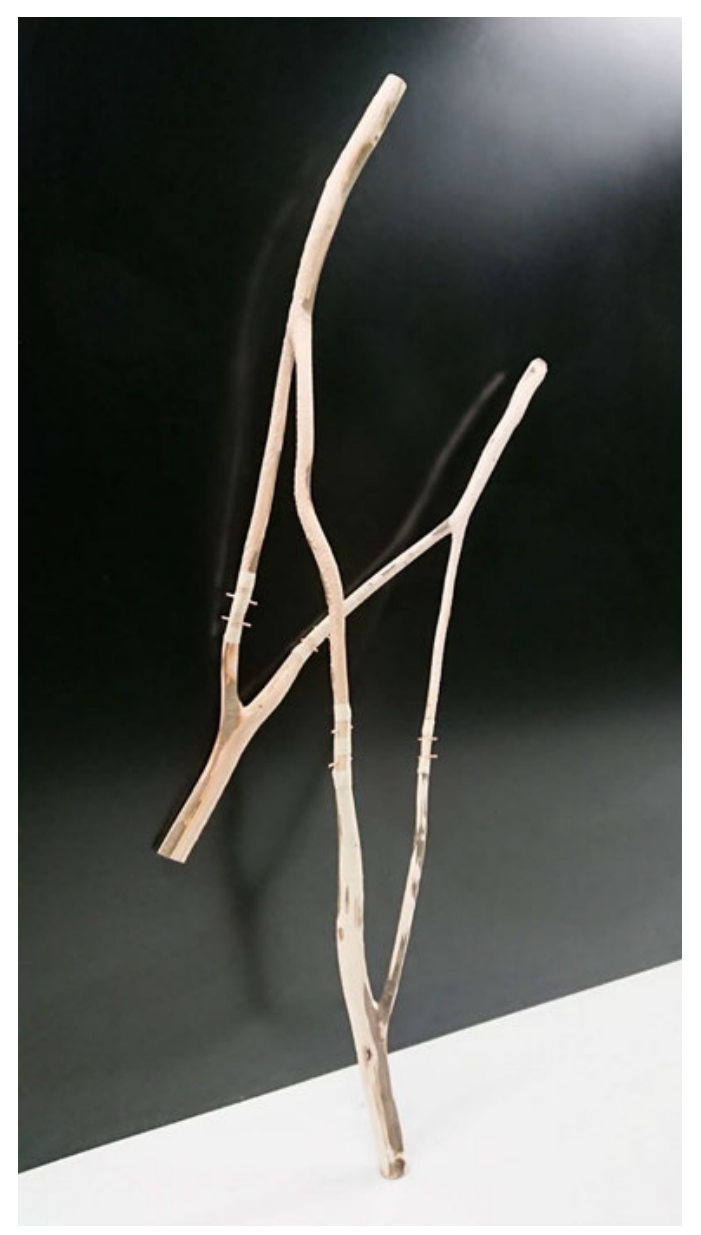

$\Delta$ Fig. 6c|Abb. 6c:

Realization of one tetrahedral cell, built from four Y-shaped hornbeam and beechwood branch forks. 

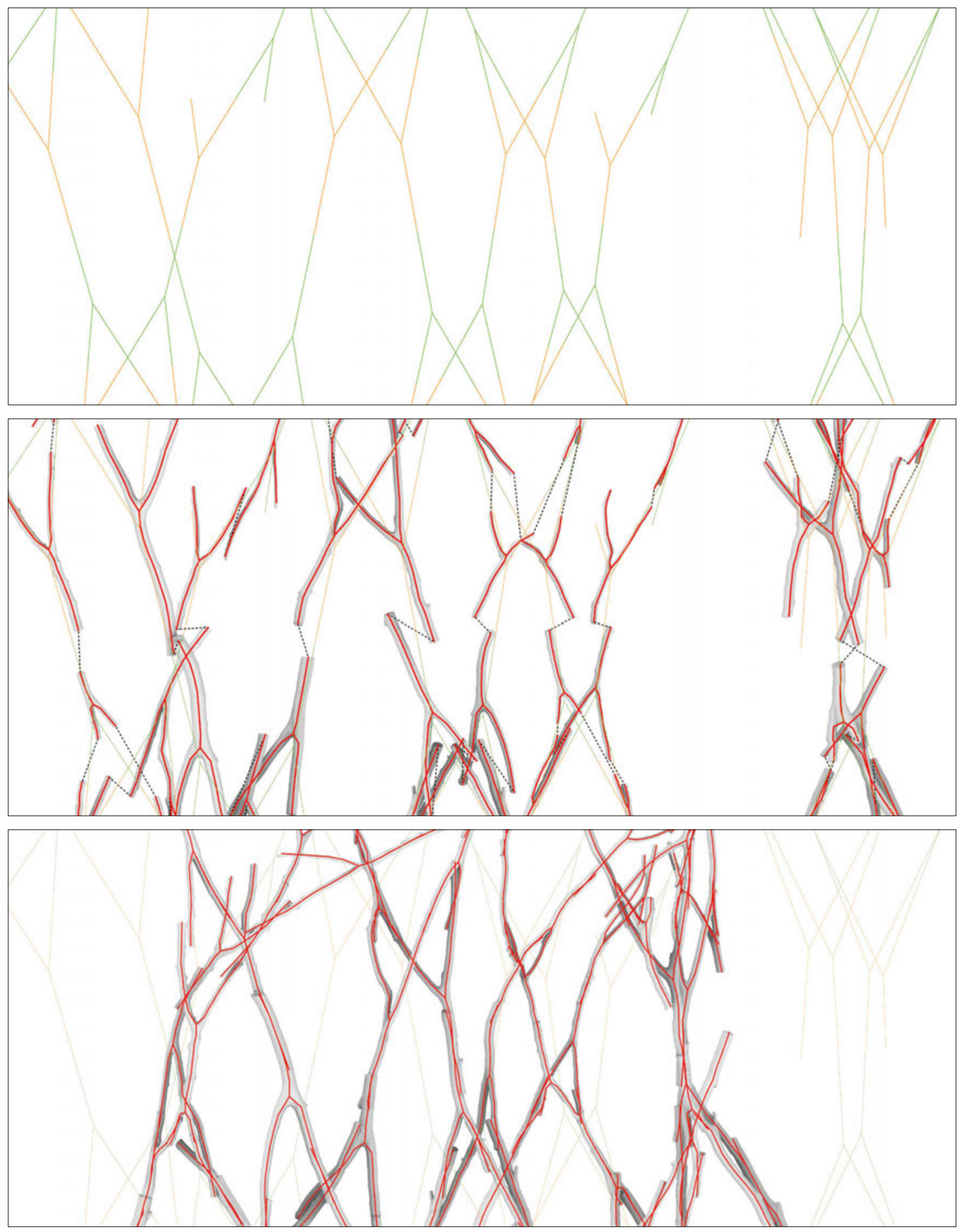

$\Delta$ Fig. 7 | Abb. 7 :

Gap compensation via force-based relaxation after replacement of the 'proto-parts' with 3D-scanned data from real branch forks: top: topological aggregation, middle: replacement with scanned data, and bottom: relaxation/realigning process. 

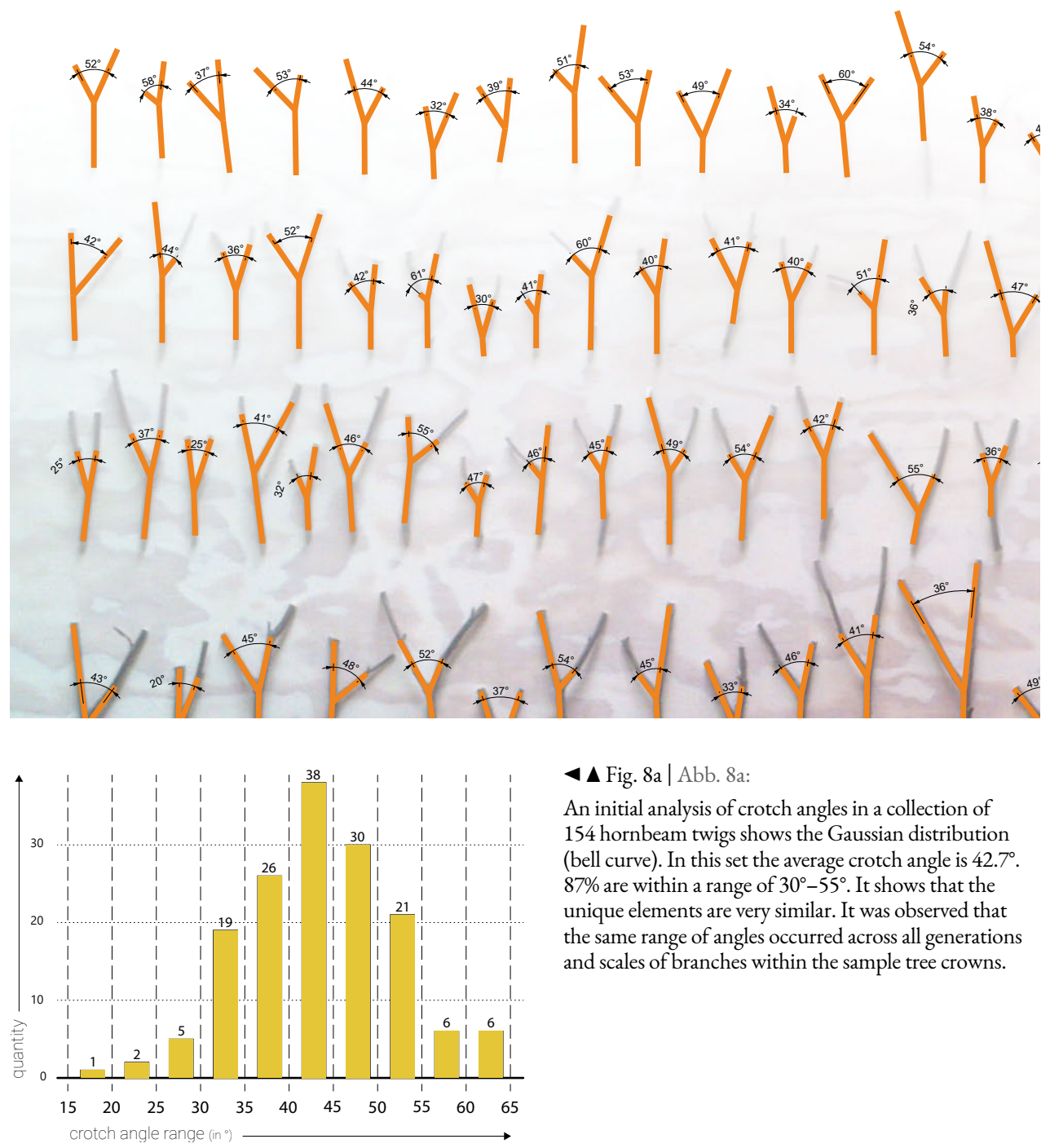

4 $\Delta$ Fig. 8a | Abb. 8a:

An initial analysis of crotch angles in a collection of 154 hornbeam twigs shows the Gaussian distribution (bell curve). In this set the average crotch angle is $42.7^{\circ}$. $87 \%$ are within a range of $30^{\circ}-55^{\circ}$. It shows that the unique elements are very similar. It was observed that the same range of angles occurred across all generations and scales of branches within the sample tree crowns.
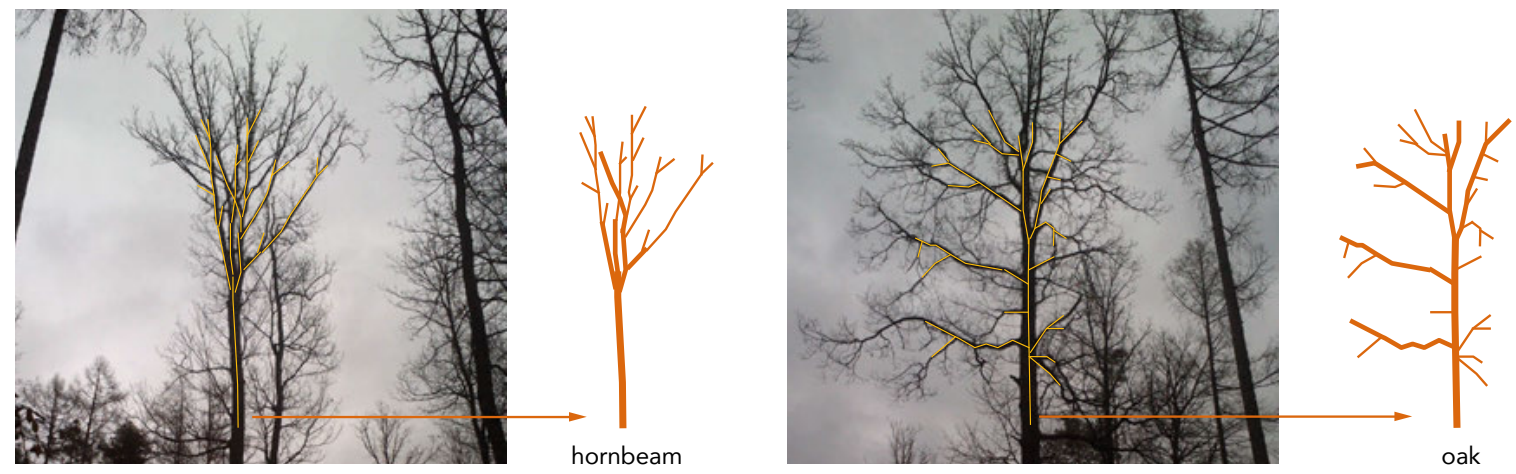

$\Delta$ Fig. 8b | Abb. 8b:

In other tree types such as oak the average crotch angle as well as minima and maxima are different, resulting in a diverging crown architecture. There is still very little research or scientific data on typical crotch angles and statistical distribution for various tree species. It was assumed that the angles ranges vary only marginally within one species under similar growth conditions. Across species, there is a larger variety of angles. 

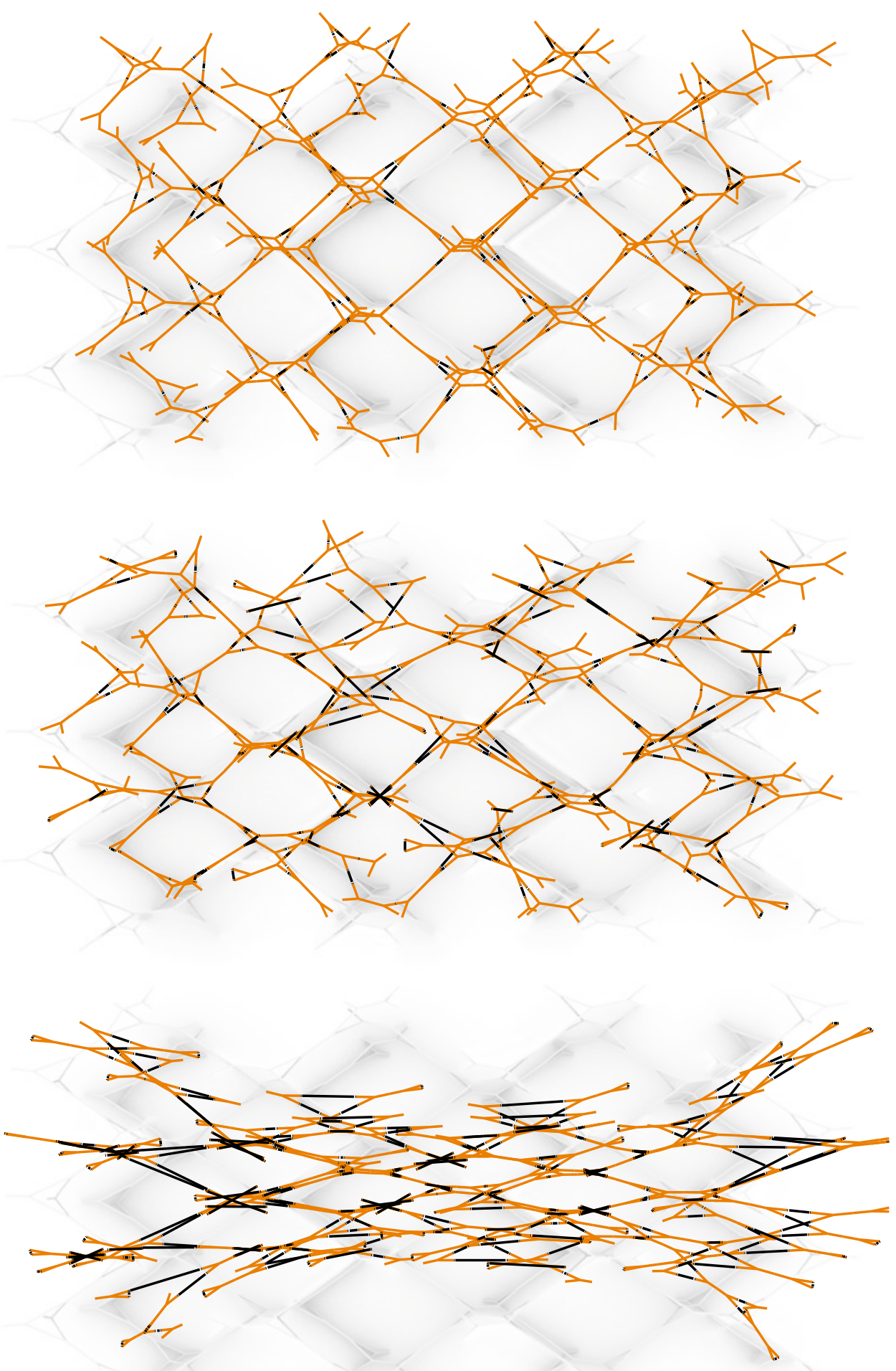

$\Delta$ Fig. $8 c \mid$ Abb. 8c:

The same 'proto-part' aggregation after random replacement with simplified branch forks with varying crotch angle ranges: $60^{\circ}-80^{\circ}$ (top), $17^{\circ}-105^{\circ}$ (middle), $23^{\circ}-30^{\circ}$ (bottom). 


\section{'MULTI-NODES'}

An implementation of branch types with more ends (Fig. 9) would open up further opportunities for structural applications. Frameworks with structural nodes that can connect more than three member axes would allow for the formation of triangles for bracing as part of its layout (Fig. 10), thus providing more design flexibility. Such manifold nodes could be established through forked branches that naturally come with multiple bifurcations. However, segments of branches could also be combined into designed components (Fig. 11).

Because of their increased stability, provided by stiff triangular cells, these components could be used in frameworks that utilize extension elements between nodes, opening up possibilities for modular design systems (Fig. 12). The irregular branch elements could be transformed into versatile components, capable of being reconfigured for various settings.

\section{MEHRFACHKNOTEN}

Das Verwenden von Astgabeln mit mehreren Enden (Abb. 9) würde weitere Möglichkeiten für strukturelle Anwendungsgebiete eröffnen. Aus strukturellen Knoten, an denen mehr als drei Stabachsen zusammentreffen, könnte man Tragwerke mit Dreiecken zur Aussteifung schaffen (Abb. 10), was mehr Designflexibilität bieten würde. Solche Verzweigungsknoten könnten Astgabeln sein, die von Natur aus mehrfache Verzweigungen aufweisen, alternativ könnten aber auch verschiedene Astgabel-Teile kontrolliert zu neuen Bauteilen zusammengesetzt werden (Abb. 11).

Durch die erhöhte Stabilität, die durch steife Dreieckszellen gegeben ist, könnten diese Bauteile in Fachwerken mit zusätzlichen, dazwischenliegenden Verlängerungsstäben verwendet werden. Das würde wiederum ermöglichen, ein modulares Konstruktionssystem anzudenken (Abb. 12). Die unregelmäßigen Astgabeln könnten somit in vielseitig einsetzbare Komponenten umgewandelt werden, die für verschiedene Szenarien neu konfigurierbar bleiben.
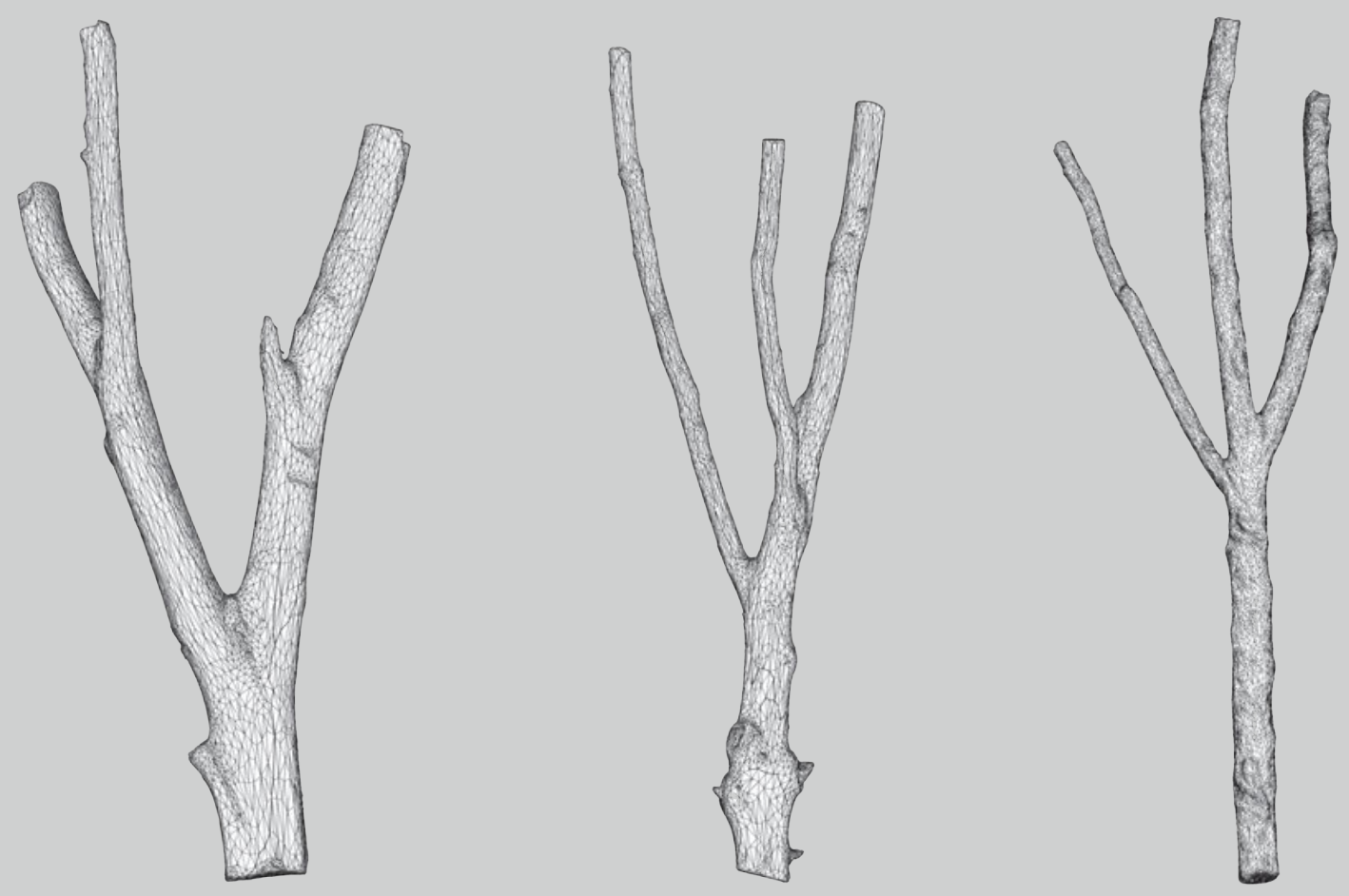

\ Fig. $9 \mid$ Abb. 9:

$3 \mathrm{D}$ scans of naturally grown elements with more than three branch ends. 


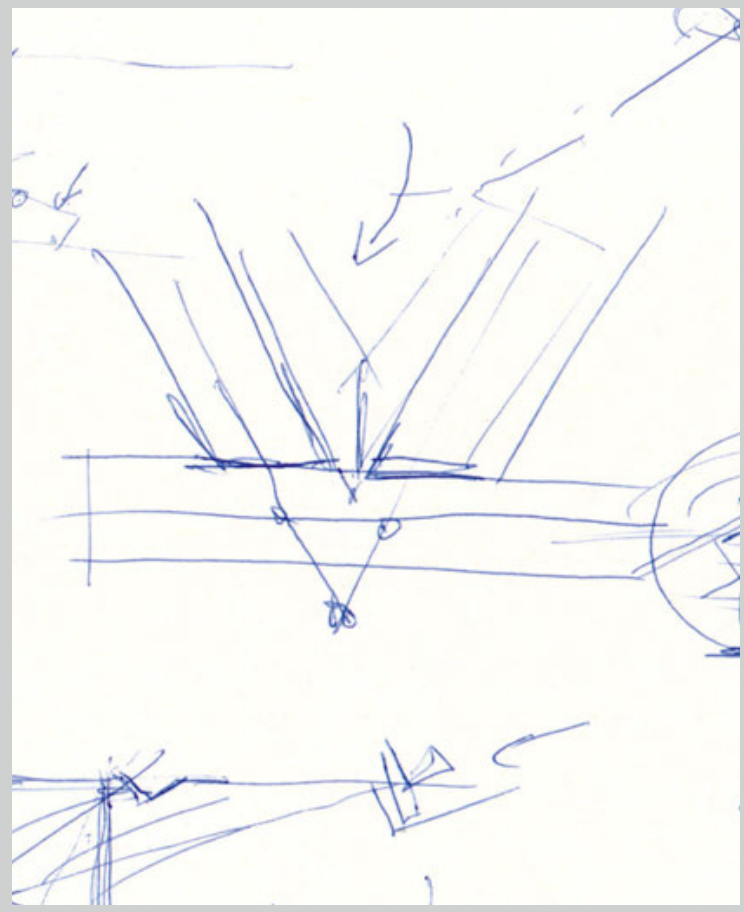

$\Delta$ Fig. $10 \mid$ Abb. 10:

Diagram of a node detail in a typical truss scheme with triangular cells (see also Approach, Fig.1b, p. 59).

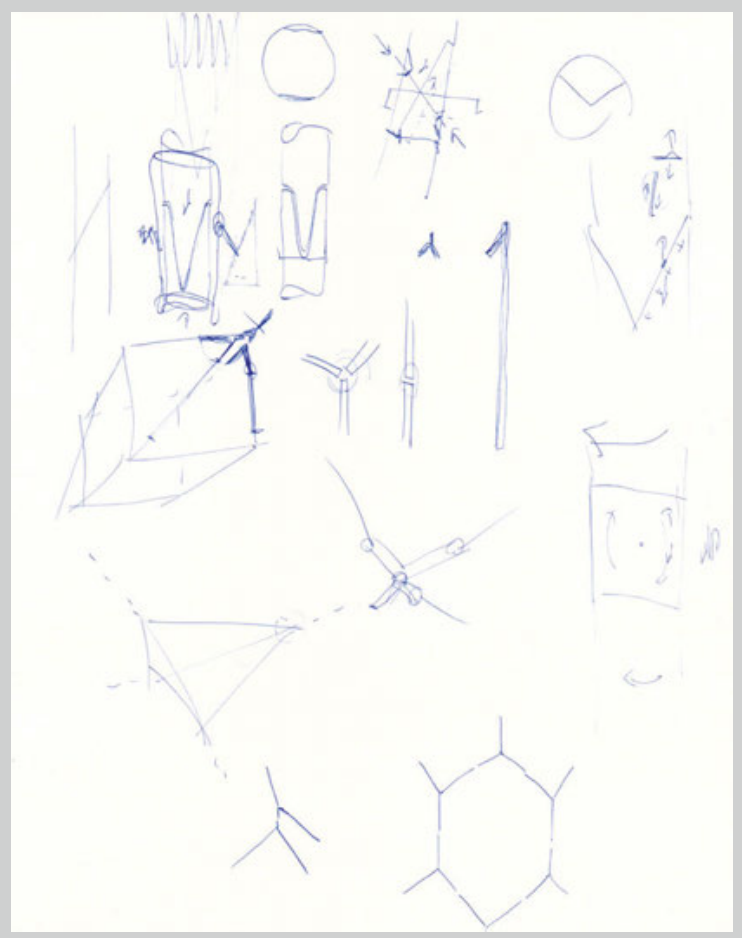

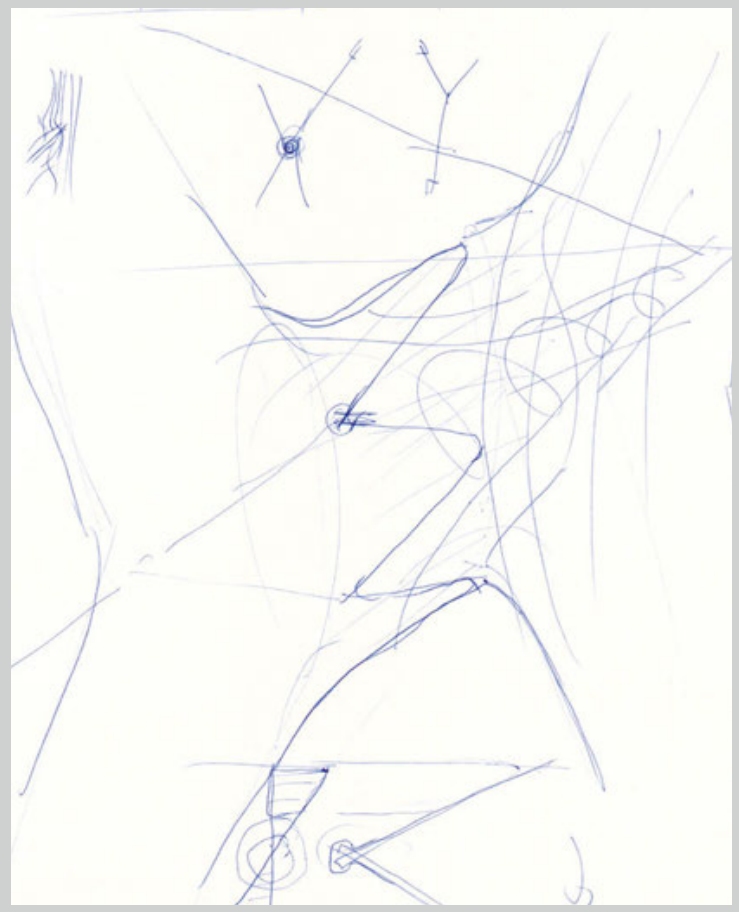

$\Delta$ Fig. $11 \mid$ Abb. 11:

Sketch of a structural node formed by two Y-shaped branch forks, glued together with finger joints.

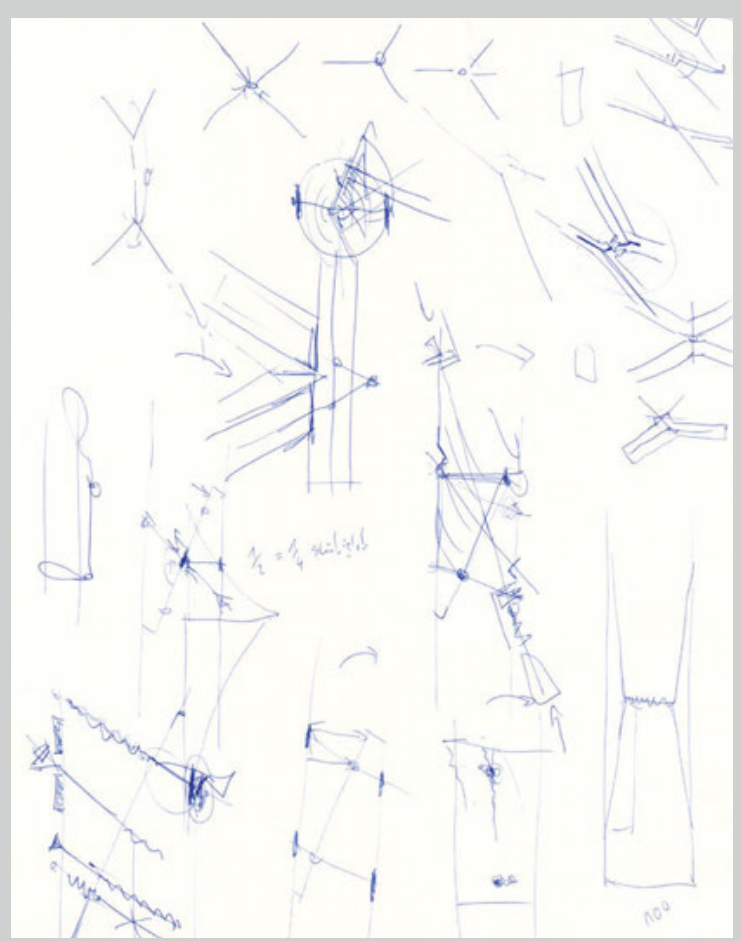

$\Delta \mathbf{\Delta}$ Fig. 12 | Abb. 12:

Sketches from a brainstorming session with Moritz Heimrath and Adam Orlinski (B+G engineers). 


\section{SORTING AS A DESIGN TOOL}

A workflow that employs a simplified framework made of identical parts as a preset for replacing the regular constituents with the actual specimens from the available set of parts offers two domains of (design) engagement. One is concerned with the global layout and topology (Fig. 13), the other addresses the local replacement of parts.

To control the population of the preliminary aggregations, various selection criteria are applicable. Parts can be categorized according to their location within the aggregation. When overlaying the initially generic constellation with organizational patterns, instances of parts can be called out for specific replacement (Fig. 14).

The sorting of items in the scanned catalog represents the complementary tool used for assigning suitable parts to locations in the pre-aggregated structure.

\section{SORTIEREN ALS \\ GESTALTUNGSWERKZEUG}

Ein Workflow, der darauf basiert, identische Bauteile in einem regelmäßigen Raumfachwerk durch tatsächliche Exemplare aus einem verfügbaren Datensatz zu ersetzen, bietet zwei Ebenen für eine (Design-)Auseinandersetzung. Die eine befasst sich mit dem globalen Layout und der Topologie (Abb. 13), die andere mit dem lokalen Austauschen von Teilen.

Um die Zusammensetzung der vorläufigen Aggregation (,Proto-Aggregation') zu steuern, waren verschiedene Auswahlkriterien anwendbar. Teile konnten nach ihrer Lage innerhalb der Aggregation kategorisiert werden. Durch Uberlagern der zunächst generischen Aggregation mit verschiedenen Organisationsmustern konnten die einzelnen Instanzen der Teile gezielt ausgetauscht werden (Abb. 14).

Ergänzend zur Auswertung der Ordnung der Teile innerhalb der ,Proto-Aggregation' konnten die Elemente im gescannten Katalog nach verschiedenen Kriterien, wie etwa Größe, Durchmesser usw., sortiert werden, um eine gezielte Zuordnung von passenden Teilen an entsprechende Stellen in dieser vorläufig generierten Struktur zu ermöglichen.

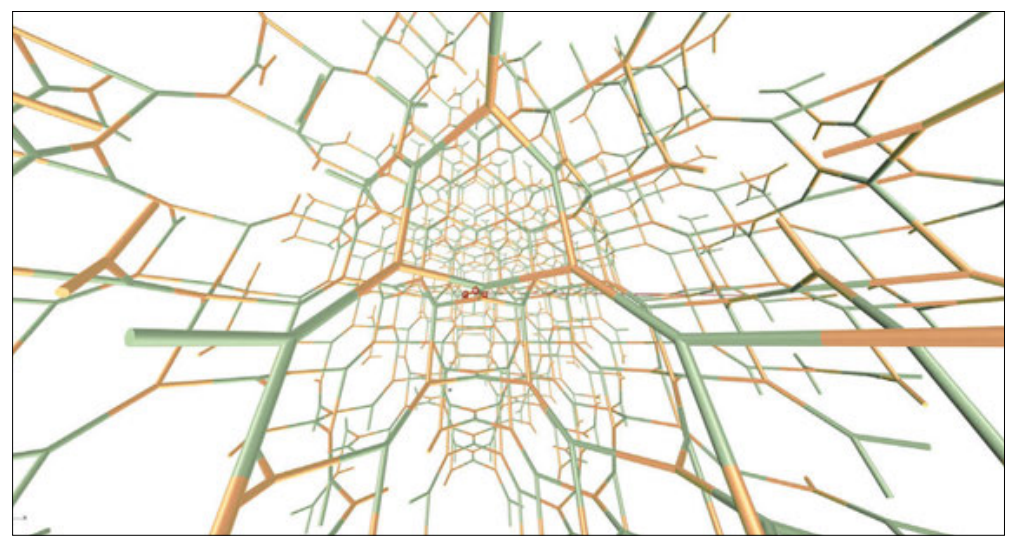

$4 \nabla$ Fig. 13| Abb. 13:

'Infinite' octahedron (left) and tetrahedron (bottom) grid structures.

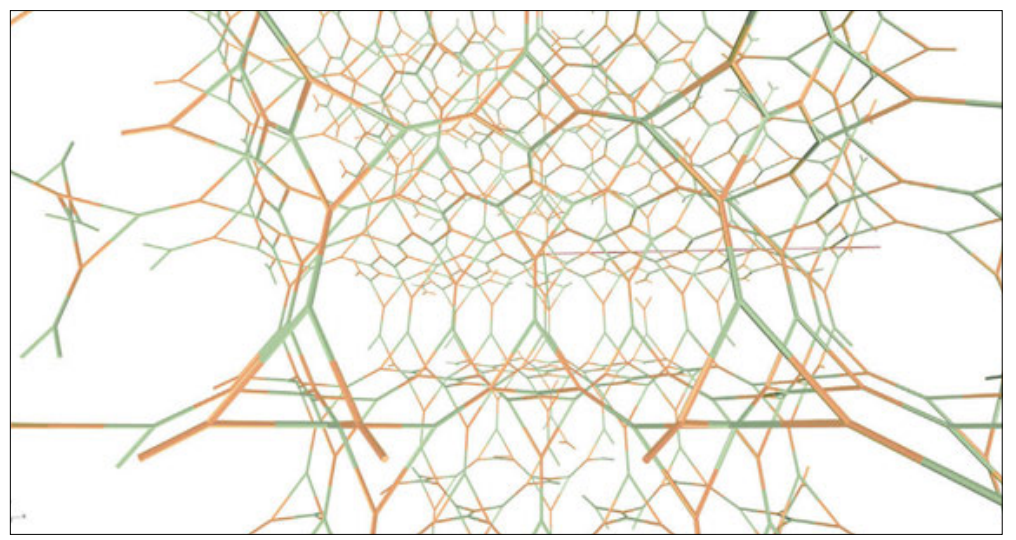



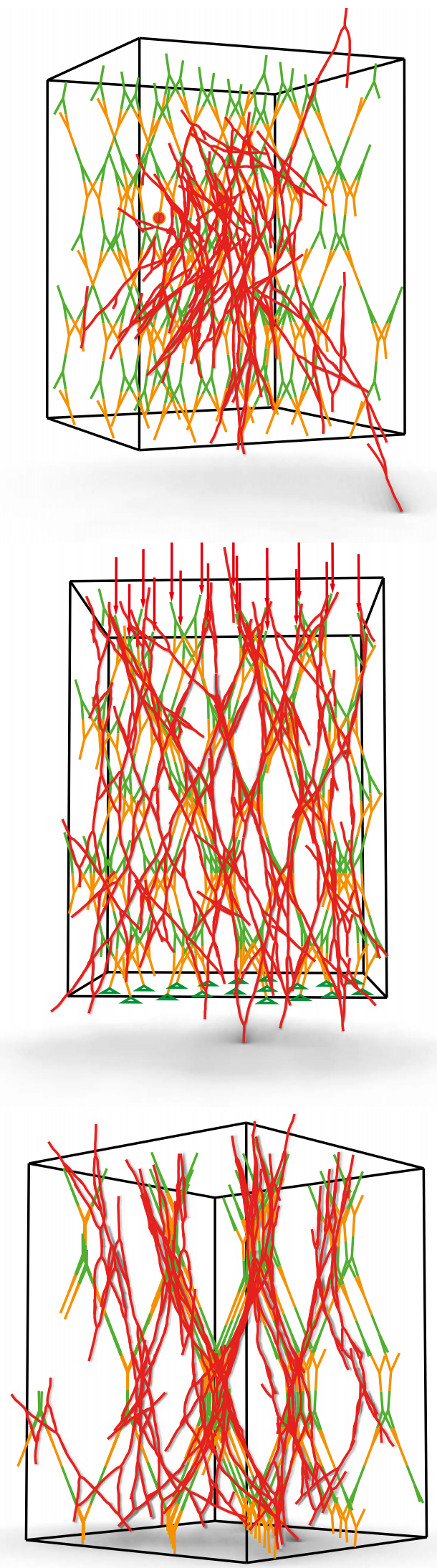

Fig. 14 Abb. 14:

Different possible sorting concepts applied to identical sets of parts result in large variations: top: Sorting of locations of part instances according to vicinity to an 'attractor' point in combination with a sorting of parts by size. middle: Assigning parts by cross section according to local utilization (simulated via structural analysis with Karamba3d). bottom: Sorting parts by crotch angle, positioning elements gradually with wide angles at the bottom and narrow angles at the top. 


\section{SPECULATIONS}

The emergent formations were understood as a kind of architectural infrastructure (Figs. 15a+b). Potential applications and activation as building structures were investigated in speculative studies. To translate the abstract frameworks into architectural scenarios that hint at possibilities for use and inhabitation, these studies were mainly invested in introducing surfaces as complementary elements (Figs. 16a-g). To cope with the ambiguity and idiosyncratic characteristics of the branch structures, speculations operated on a geometric level, neglecting distinct material aspects, to leave space for further reflection and interpretation.

In a collaboration with performance artists Lucie Strecker and Daniel Aschwanden, an interpretative interaction of technical structures and organic bodies was practiced through the means of performance art.

The second prototype (Fig. 17) $\nearrow^{32}$ was activated as a multidimensional stage for various performance activities as part of the trans-disciplinary multimedia art project Deep Dreaming Creatures ${ }^{5}$ (Fig. 18).

\section{SPEKULATIONEN}

Die so entstehenden Formationen wurden als eine Art architektonische Infrastruktur verstanden (Abb. 15a+b). Mögliche Anwendungen und Aktivierungen als Gebäudestrukturen wurden in spekulativen Studien untersucht. Um die abstrakten Gefüge in architektonische Szenarien zu übersetzen, die Möglichkeiten einer Nutzung und Bewohnbarkeit andeuten, wurden in diesen Studien vor allem Oberflächen als ergänzende Elemente eingeführt (Abb. 16a-g). Um mit der Uneindeutigkeit und der eigenwilligen Charakteristik der Aststrukturen umzugehen, bewegten sich die Spekulationen auf einer geometrischen Ebene, eindeutige materielle Aspekte wurden bewusst vernachlässigt, um Raum zu lassen für weitere Überlegungen und Interpretationen.

In einer Zusammenarbeit mit den Performance-Künstlern Lucie Strecker und Daniel Aschwanden wurde zudem ein interpretatives Zusammenspiel von technischen Strukturen und organischen Körpern mit den Mitteln der PerformanceKunst ausgelotet.

Der zweite Prototyp (Abb. 17) $\nearrow^{32}$ diente dabei als mehrdimensionale Bühne für verschiedene Aktivitäten im Rahmen des interdisziplinären Multimedia-Kunstprojekts Deep Dreaming Creatures ${ }^{5}$ (Abb. 18).

1 Spindler, K. (1995): “Wooden handle of the copper axe used by the Neolithic hunter Oetzi 5,000 years ago", in: Spindler, K.: Der Mann im Eis, München: Goldmann.

2 Mollica, Z., Self, M. (2016): “Tree fork truss”, in: Adriaenssens, S., Gramazio, F., et al. (eds.): Advances in Architectural Geometry, Zürich: vdf Hochschulverlag, ETH Zürich: 138-153.

3 Hanewinkel, M. (2010): Baumarteneignung Fichte und Buche bei Klimawandel, http://www.waldwissen.net.

$4 \quad$ Schüler, S., Grabner, M., et al. (2013): “Fichte - fit für den Klimawandel?”, in: BFW-Praxisinformation 31: 10-12.

5 Deep Dreaming Creatures: Daniel Aschwanden and Lucie Strecker in collaboration with brut Vienna, Lukas Allner and Daniela Kröhnert, Jens Hauser, David Berry, Ben James, Vera Sebert and Philippe Riera, 2021. 

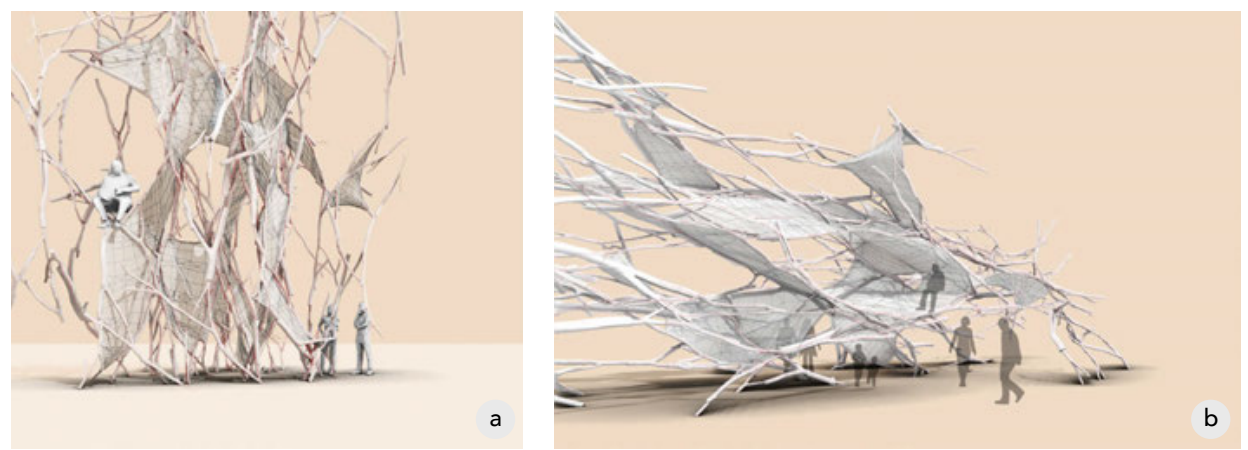

$\Delta \mathbf{\Delta}$ Figs. $15 \mathrm{a}+\mathrm{b} \mid$ Abb. $15 \mathrm{a}+\mathrm{b}$ :

Use case studies with tensile fabric surfaces within horizontally (a) and vertically (b) oriented branch formations.
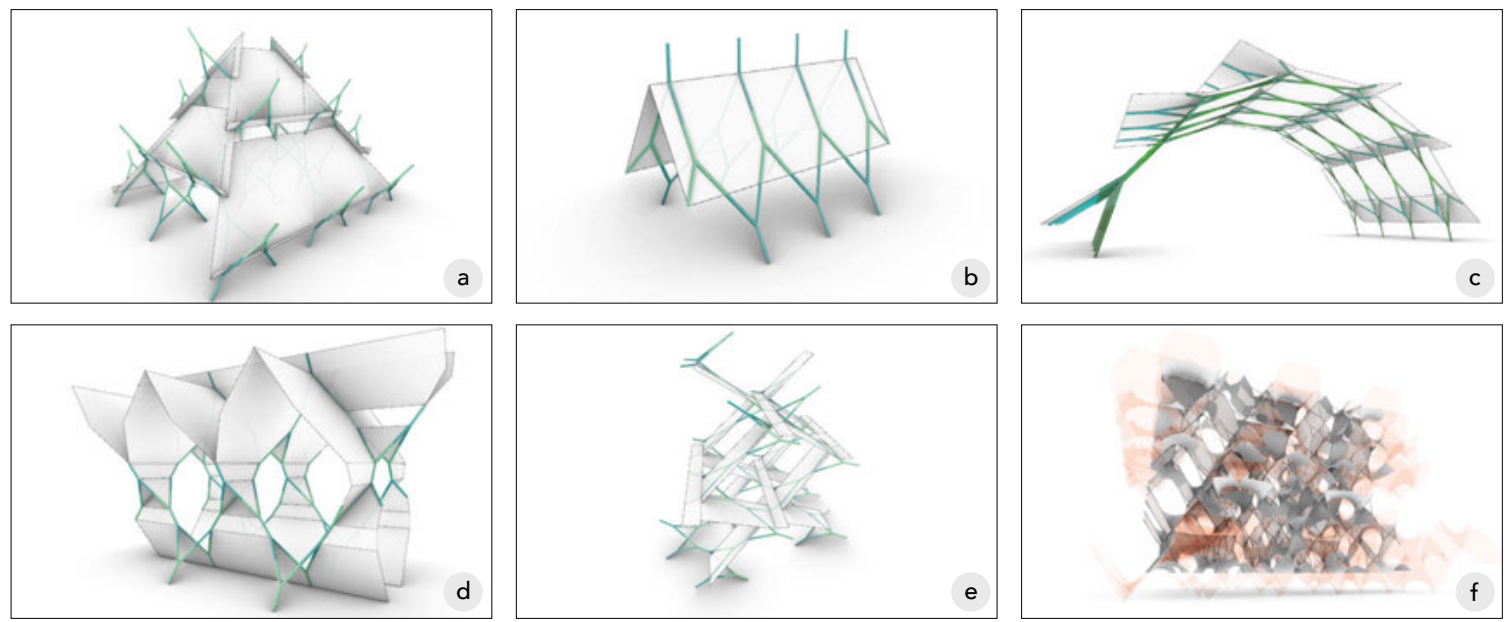

\ Figs. 16 a-f | Abb. 16a-f:

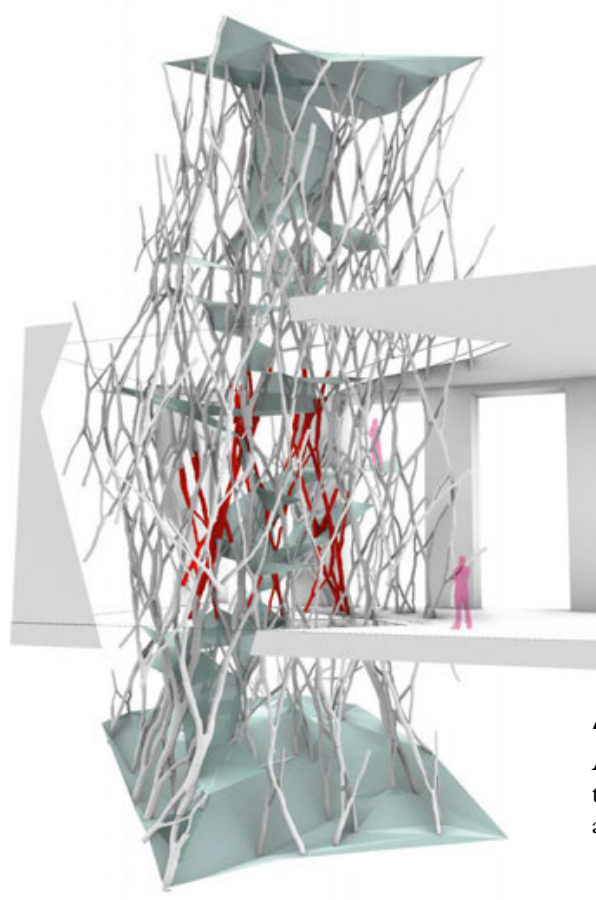

Studies of simplified frameworks as different schematic architectural typologies (roof, ramps/floors, envelope).

A Fig. $16 \mathrm{~g}$ | Abb. $16 \mathrm{~g}$ :

Architectural scenario as envisioned for the demonstrator in the Conceptual Joining show at AIL 2019: A branch formation as scaffolding supporting a series of ramps and floor plates. 


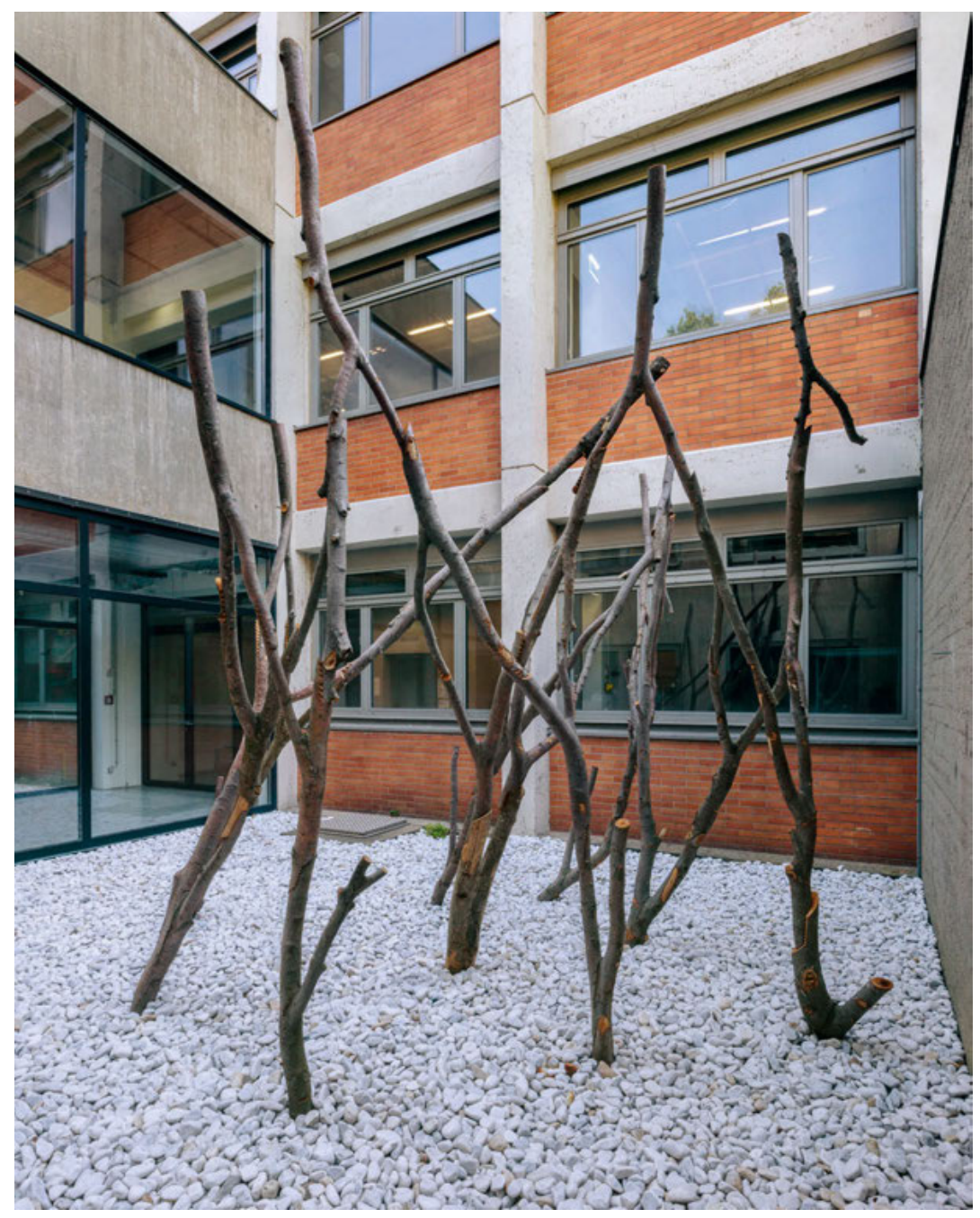

A Fig. 17 | Abb. 17:

Full-scale realization at the University of Applied Arts Vienna, 2021.

Photo $\odot$ Thomas Steineder

- Fig. 18 | Abb. 18 :

Performance artists Lucie Strecker and Daniel Aschwanden interacting with the branch formation as part of the transdisciplinary project Deep Dreaming Creatures.

Photo $\odot$ Daniel Aschwanden, Lucie Strecker 



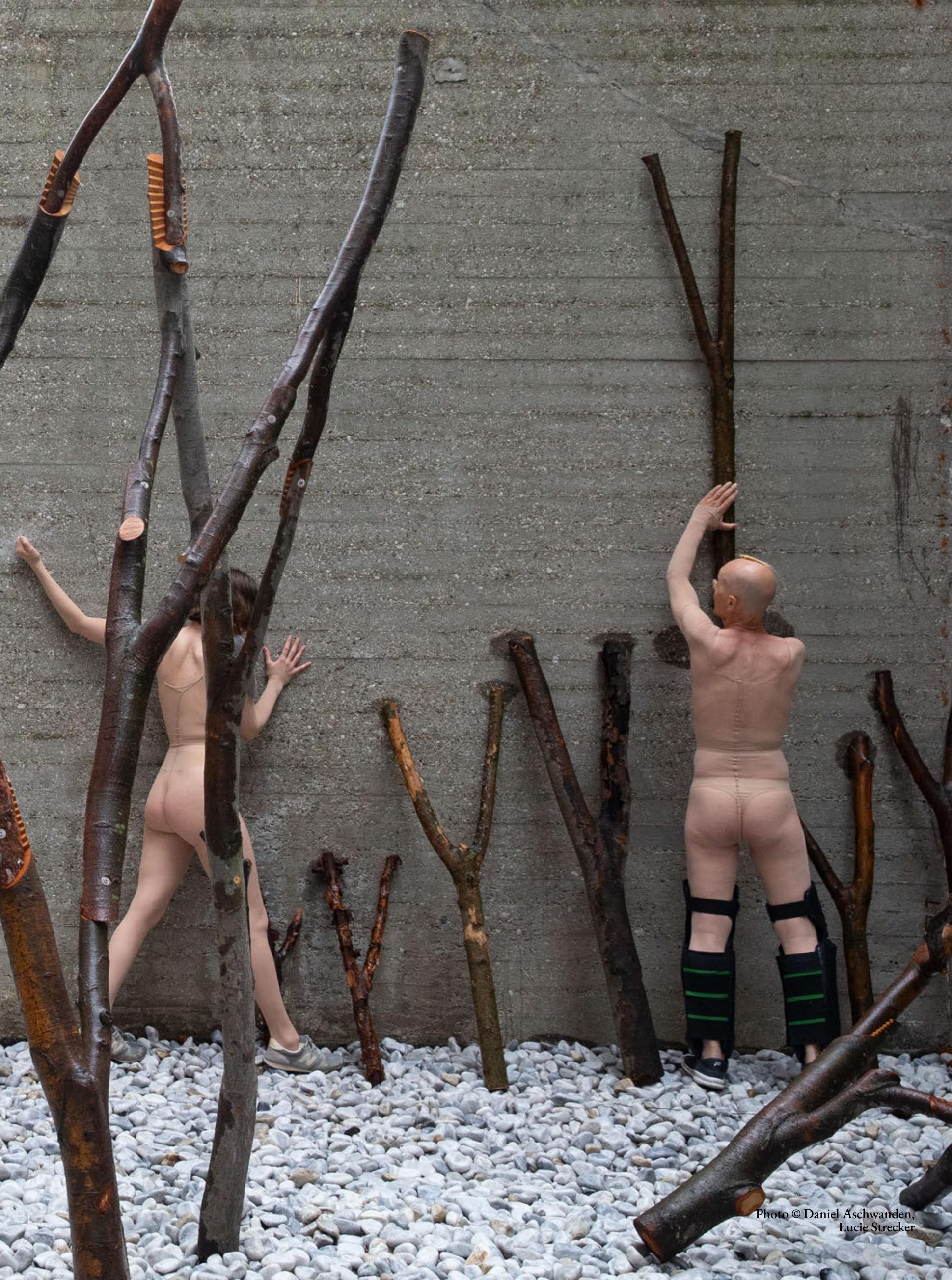

